\title{
PENGARUH PENGUNGKAPAN GOOD CORPORATE GOVERNANCE TERHADAP NILAI PERUSAHAAN PADA BADAN USAHA MILIK NEGARA YANG TERDAFTAR DI BURSA EFEK INDONESIA PERIODA 2013-2017
}

\author{
Stevi Jimry Poluan ${ }^{1}$, Arya Aditya Wicaksono ${ }^{2}$ \\ Universitas Ma Chung Malang \\ stevi.jimry@machung.ac.id
}

\begin{abstract}
This study aims to prove the impact of Good Corporate Governance on Firm Value in Badan Usaha Milik Negara that listed in Indonesian Stock Exchange. This study used 4 varibles that represented Good Corporate Governance which is Managerial Ownership, Institusional Ownership, Board of Independent Commissioner, and Audit Committee. Meanwhile Tobin's Q ratio used to counted Firm Value. Population of this research are all Badan Usaha Milik Negara that listed in Indonesian Stock Exchange on 2013 until 2017. There are 20 firm are listed. The total samples are 16 firms selected by using purposive sampling method. Data anlysis and hypothesis testing using multiple regression. From 4 variable that used in this research only 2 that had an effect on firm value. There were Institusional Ownership and Audit Committee. This research prove that Institusional Ownership has a positive and significant effect on firm value. Audit Committee had a negative and insignificant effect on firm value. Other 2 variable like Managerial Ownership, Board of Independent Commissioner has not effect on firm value, while Audit Committee has negative effect on firm value..
\end{abstract}

Keyword: Good Corporate Governance, Managerial Ownership, Institutional Ownership, Board of Independent Commissioner, Audit Committee, Firm Value

\begin{abstract}
ABSTRAK
Penelitian ini bertujuan untuk menguji pengaruh Good Corporate Governance terhadap nilai perusahaan pada Badan Usaha Milik Negara yang terdaftar di Bursa Efek Indonesia. Penelitian ini menggunakan 4 variabel pengungkapan Good Corporate Governance yaitu Kepemilikan Manajerial, Kepemilikan Institusional, Komisaris Independen, dan Komite Audit. Sedangkan nilai perusahaan pada penelitian ini dihitung menggunakan rumus Tobin's $Q$. Populasi dari penelitian ini adalah seluruh perusahaan yang merupakan Badan Usaha Milik Negara yang terdarftar di Bursa Efek Indonesia periode 2013-2017. Jumlah total Badan Usaha Milik Negara yang terdaftar di Bursa Efek Indonesia adalah 20 perusahaan. Dari populasi tersebut terdapat 16 sampel yang diambil dengan menggunakan metode purposive sampling. Teknik analisis data dan pengujian hipotesi pada penelitian ini menggunakan regresi linier berganda. Dari 4 variabel yang digunakan dalam penelitian ini hanya 2 variabel yang memiliki pengaruh terhadap nilai perusahaan. Variabel tersebut adalah Kepemilikan Institusional dan Komite Audit. Variabel kepemilikan institusional dalam penelitian ini memiliki pengaruh positif dan signifikan terhadap nilai perusahaan. Variabel Komite Audit dalam penelitian ini memiliki pengaruh yang negatif dan tidak signifikan terhadap nilai perusahaan. Sedangkan 2 variabel lain yaitu kepemilikan manajerial dan komisaris independent tidak memiliki pengaruh terhadap nilai perusahaan. .
\end{abstract}

Kata Kunci: Good Corporate Governance, Kepemilikan Manajerial, Kepemilikan Institusional, Komisaris Independen, Komite Audit, Nilai Perusahaan.

\section{PENDAHULUAN}

Nilai perusahaan saat ini merupakan sebuah perhatian penting bagi perusahaan. Nilai perusahaan ini pun merupakan sebuah cerminan dari kinerja perusahaan (Suharli,
2006) yang juga sebuah indicator bagi pasar untuk menilai perusahaan secara keseluruhan (Nurlela, 2008). Dalam proses meningkatkan nilai perusahaan perlu adanya kerjasama pihak terkait dalam perusahaan yang sering kita sebut 
juga stakeholder. Maka perlu adanya system yang mengakomodasi keinginan dan kebutuhan stakeholder untuk mencegah terjadinya agency conflict (Jansen and Mecking, 1976), (Embang, 2016).

Agency conflict terjadi karena manajer mengutamakan kepentingan pribadi yang berlawanan dengan kepentingan pemegang saham yang menyebabkan kerugian bagi perusahaan yang berujung pada penurunan nilai perusahaan (Jensen and Meckling, 1976). Untuk mencegah terjadinya agency conflict maka perlu adanya Good Corporate Governance. Good Corporate Governance merupakan salah satu cara untuk meningkatkan nilai perusahaan sekaligus meminimalisasi terjadinya agency conflict. Agency conflict tersebut nantinya akan menimbulkan biaya yang sering juga disebut sebagai agency cost. Langkah yang dapat diambil oleh perusahaan untuk mengurangi agency cost adalah melibatkan manajemenn dalam kepemilikan saham yang bertujuan untuk penyetaraan kepentingan pemegang saham. Peningkatan kepemilikan manajerial membantu untuk menghubungkan kepentingan pihak internal dan pemegang saham, dan mengarah ke pengambilan keputusan yang lebih baik dan meningkatkan nilai perusahaan (Damayanti \& Suartana, 2014)

Struktur kepemilikan lain dalam mekanisme Good Corporate Governance yang dapat meningkatkan nilai perusahaan dan mengurangi terjadinya agency conflict adalah Kepemilikan Institusional. Kepemilikan institusional merupakan kepemilikan saham oleh instutisi atau Lembaga tertentu. Tingginya jumlah kepemilkan institusional akan meningkatkan sistem kontrol perusahaan yang ditujukan guna meminimalisasi tingkat kecurangan akibat tindakan oportunistik pihak manajemer yang nantinya dapat mengurangi nilai perusahaan (Damayanti \& Suartana, 2014).

Dua mekanisme good corporate governance lain yang dapat meningkatkan nilai perusahaan dan mengurangi agency conflict adalah adanya komisaris independen dan komite audit dalam sebuah perusahaan. Dewan komisaris independen akan membina sistem akuntansi yang efektif agar akuntabilitas perusahaan dapat tercapai sedangkan komite audit bertugas memastikan perusahaan memberikan pertanggungjawaban atau konsekuensi logis dari kepercayaan dan wewenang yang diberikan oleh pemangku kepentingan kepada pengelola perusahaan (Hadiwidjaja, 2018). Komite audit itu sendiri dibentuk oleh dewan komisaris independen untuk menjalankan fungsi pengawasan atas proses pelaporan keuangan sehingga mewujudkan sistem pengawasan yang memadai yang nantinya akan memelihara kredibilitas perusahaan serta meningkatkan nilai perusahaan.

Keempat mekanisme tersebut diharpakan dapat mengurangi agency conflict serta meningkatkan nilai perusahaan dengan menerapkan fungsi pengawasan. Orchad (2016) juga menambahkan bahwa keseimbangan kewenangan antara direksi, komisaris, dan pemegang saham dirancang sedemikian rupa dengan menerapkan prinsipprinsip Good Corporate Governance sehingga mekanisme dan struktur kelembagaan perusahaan dapat berjalan sesuai dengan

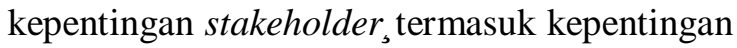
masyarakat luas.

Di Indonesia sendiri praktik Good Corporate Governance belum berjalan dengan baik. Hal ini dibuktikan dengan pernyataan Ketua Dewan Komisioner OJK Wimboh Santoso yang menyatakan bahwa hanya 2 emiten dari Indonesia yang masuk dalam daftar 50 emiten terbaik dalam praktik Good Coporate Governance di Asean yaitu PT. Bank Danamon Tbk dan PT Bank CIMB Niaga Tbk. Pencapain ini tentu masih tertinggal jauh dari Thailand yang menempatakn 23 emiten, Filipina 11 emiten, Singapura 8 emiten, dan Malaysia 6 emiten (Primadhyta, 2017). Oleh karena itu, tata kelola perusahaan yang baik menjadi perhatian khusus bagi Pemerintah Indonesia. Pada dasarnya penerapan Good Corporate Governance telah diatur oleh 
pemerintah khususnya bagi perusahaan swasta dan Badan Usaha Milik Negara (BUMN). Menurut Peraturan Menteri Negara BUMN nomor PER-01/MBU/2011 Good Corporate Governanvce adalah prinsip- prinsip yang mendasari suatu proses dan mekanisme pengelolaan perusahaan berlandaskan peraturan perundang- undangan dan etika berusaha.

Pada dasarnya perusahaan swasta dan

BUMN tidaklah jauh berbeda yang membedakan hanya kepemilikannya yang dimana BUMN sebagian besar milik negara. Maka dari itu perlu adanya prinsip kehatihatian harus selalu diutamakan dalam menjunjung tinggi profesionalitas karena banyak kondisi yang dapat mempengaruhi kinerja BUMN sehingga membedakannya dengan perusahaan swasta (Orchad, 2016). Toto Pranoto menyatakan bahwa dalam prakteknya seringkali tantangan yang dihadapi pengelolalan BUMN dalam melaksanakan Good Corporate Governance terhambat oleh tiga faktor utama. Pertama adalah terlalu banyaknya kepentingan dari pemerintah yang terkadang bertolak belakang, sehingga menyulitkan manajemen BUMN dalam menentukan objektifitas perusahaan. Kedua, manajemen diberikan kewenangan terbatas atau terlalu kuat aroma politik dalam penempatan direksi, sehingga menyulitkan dalam pengambilan keputusan yang objektif. Ketika, manajemen diberikan sistem intensif yang kurang menarik sehingga kinerjanya terbatas. Pernyataan ini sejalan dengan pernyataan yang sampaikan oleh Nugroho dan Siahaan (2005) yang menyatakan bahwa terdapat kekaburan pemisahan antara kepentingan bisnis dan kepentingan pemerintah maupun Lembaga negara yang lain. Akibatnya berbagai keputusan bisnis di BUMN sangat di intervensi oleh pemerintah dan dalam kasus yang lain BUMN justru diekspolitasi oleh para politisi.

Good Corporate Governance sudah menjadi suatu keharusan bagi BUMN. Seperti yang sudah di atur pada Peraturan Menteri
Negera BUMN nomor PER-01/MBU/2011, penerapan tersebut bertujuan agar BUMN mengoptimalkan nilai BUMN agar perusahaan memiliki daya saing yang kuat, baik secara nasional maupun Internasional, sehingga mampu mempertahankan keberadaannya dan hidup berkelanjutan untuk mencapai maksud dan tujuan BUMN; mendorong pengelolaan BUMN secara professional, efisien, dan efektif, serta memberdayakan fungsi dan meningkatkan kemandirian Organ persero; mendorong agar Organ Persero/ Organ Perum dalam membuat keputusan dan menjalankan tindakan dilandasi nilai moral yang tinggi dan kepatuhan terhadap peraturan perundangundangan, serta kesadaran akan adanya tanggung jawab sosial BUMN terhadap pemangku kepentingan maupun kelestarian lingkungan di sekitar BUMN; meningkatkan kontribusi BUMN dalam perekonomian nasional dan menungkatkan iklim yang kondusif bagi perkembangan investasi nasional.

Penelitian tentang pengaruh Good Corporate Governance terhadap nilai perusahaan sudah pernah dilakukan sebelumnya. Seperti penelitian yang dilakukan oleh Nugroho (2015), Gultom dan Ahmar (2016), Onasis (2016), Marcelin dan Harsono (2017), dan Hadiwidjaja (2018) menunjukan hasil yang tidak konsisten mengenai pengaruh Good Corporate Governance terhadap nilai perusahaan. Maka dari itu, tujuan dari penelitian ini adalah menganalisa kembali pengaruh dari Good Corporate Governance melalui kepemilikan manajerial, kepemilikan institusional, komisaris independen, dan komite audit pada Badan Usaha Milik Negara yang terdaftar di Bursa Efek Indonesia periode 2013- 2017.

\section{TINJAUAN PUSTAKA}

Dalam proses pengawasan perusahaa, para pemegang saham akan mengelurakan biaya pengawassan yang biasa disebut juga sebagai agency cost. Agency cost dapat dikurangi dengan meningkatkan kepemilkan manerial dalam sebuah perusahaan. Dengan 
adanya keterlibatan kepemilikan saham oleh manajer, diharapkan manajer dapat bertindak dengan mempertimbangkan segala resiko yang ada serta memotivasi diri untuk meningkatkan kinerjanya dalam mengelola perusahaan (Ningsih, 2013). Beberapa penelitian menunjukan hasil yang kurang konsisten tentang pengaruh kepemilikan manajerial dengan nilai perusahaan. Seperti penelitian yang dilakukan olejh Damayanti dan Suartana (2014) menunjukan bahwa kepemilikan manajerial tidak berpengaruh terhadap nilai perusahaan. Berbeda dengan penelitian yang dilakukan oleh Achmad dan Rovila (2014) yang menyatakan bahwa kepemilkan manajerial mempengaruhi nilai perusahaan.

H1 : Kepemilikan Manajerial mempengaruhi nilai perusahaan

Kepemilikan instusional sendiri memiliki pengaruh penting dalam proses pengawasan kinerja sebuah perusahaan. Dengan adanya kepemilikan Institusional segala bentuk aktivitas perusahaan akan diawasi oleh pihak institusi atau Lembaga. Sehingga perusahaan akan lebih berhati- hati dalam setiap pengambilan keputusan (Purwaningtyas dan Pangestuti, 2011) dan terharah pada pencapaian nilai perusahaan yang tinggi (Haruman, 2008). Penelitian yang dilakukan oleh Damayanti dan Suartana (2014) menunjukan bahwa kepemilikan institusional memiliki pengaruh terhadap nilai perusahaan. Sedangkan penelitian yang dilakukan oleh Embang (2016) dan Hadiwidjaja (2018) menunjukan hasil yang sebalikanya

H2 : Kepemilikan Institusional memiliki pengaruh terhadap nilai perusahaan

Keberadaan komisaris independen dalam sebuah perusahaan juga tidak kalah pentingnya. Dengan adanyan komisaris independen, maka akan mengurangi konflik agensi dalam perusahaan sehingga perusahaan dapat berfokus pada peningkatan nilai perusahaan (Harjoto dan Jo, 2007). Poluan (2013) menambahkan untuk menjamin pelaksanaan good corporate governance maka diperlukan dewan komisaris independen yang berintegritas, berkemampuan, tidak cacat hukum dan independen, serta tidak memiliki hubungan bisnis ataupun hubungan lainnya dengan pemegang saham mayoritas dan dewan direksi secara langsung maupun tidak langsung. Dengan begitu maka penerapan good corporate governance akan terlaksana dengan baik dengan adanya pengawasan yang baik akan mampu meningkatkan nilai perusahaan. Beberapa penelitian sebelumnya menunjukan hasil yang tidak konsisten. Penelitian yang dilakukan oleh Wedayathi dan Darmayanti (2016) menunjukan bahwa keberadaan komisaris independen tidak memiliki pengaruh terhadap nilai perusahaan sedangkan penelitian yang dilakukan oleh Saputra (2018) menunjukan keberadaan komiaris independen memiliki pengaruh terhadap nilai perusahaan.

H3: Komisaris Independen memiliki pengaruh terhadap nilai perusahaan

Untuk menjalankan tugas pengawasannya Dewan Komisaris akan dibantu oleh para komite yang salah satunya adalah Komite Audit. Komite Audit merupakan usaha perbaikan terhadap cara pengelolaan perusahaan terutama cara pengawasan terhadap manajemen perusahaaan, karena akan menjadi penghubung antara manajemen perusahaan dengan dewan komisaris dan pihak eksternal lainnya (Onasis dan Robin, 2016). Tugas pokok dari Komite Audit itu sendiri adalah melakukan fungsi pengawasan yang yang berkaitan dengan review sistem pengendalian internal perusahaan, memastikan kualitas laporan keuangan, dan meningkatkan kefektifan fungsi audit (Hadiwidjaja, 2018). Maka dari itu diharapkan dengan adanya komite audit fungsi pengawasan dapat mengurangi agency conflict yang terjadi di perusahaan. Penelitian yang dilakukan oleh Felmania (2014) menunjukan bahwa keberadaan komite audit tidak mempengaruhi nilai perusahaan sedangkan penelitian yang dilakukan oleh Syafitri et al, 2018) menunjukan bahwa keberadaan komite adit mampu mempengaruhi nilai perusahaan.

H4: Komite audit mempengaruhi nilai perusahaan 


\section{METODE PENELITIAN}

Penelitian ini merupakan penelitian kuantitatif dengan menggunakan alat analisis regresi linier berganda dengan model sebagai berikut:

$$
Y=\alpha+\beta_{1} X_{1}+\beta_{2} X_{2}+\beta_{3} X_{3}+\beta_{4} X_{4}
$$

Keterangan:

$\mathrm{Y}=$ Nilai perusahaan

$\alpha=$ Konstanta

$\beta=$ Koefisien Regresi $X$

$\mathrm{X}_{1}=$ Kepemilikan Manajerial

$\mathrm{X}_{2}=$ Kepemilikan Institusional

$\mathrm{X}_{3}=$ Komisaris Independen

$\mathrm{X}_{4}=$ Komite Audit

Sampel pada penelitian ini adalah 16 Badan Usaha Milik Negara yang terdaftar di Bursa Efek Indonesia periode 2013- 2017 dengan Teknik purposive sampling dengan syarat sebagai berikut: 1. Badan Usaha Milik Negara yang terdaftar di Bursa Efek Indonesia pada periode 2013- 2017. 2. Badan Usaha Milik Negara yang mempublikasikan laporan tahunan mulai tahun 2013- 2017.

\section{HASIL DAN PEMBAHASAN}

Tabel 1. Uji Asumsi Klasik

\begin{tabular}{|l|l|}
\hline Uji Asumsi Klasik & Hasil \\
\hline Uji Normalitas (K-S) & Memenuhi \\
\hline $\begin{array}{l}\text { Uji Multikolinearitas } \\
\text { (Glejser) }\end{array}$ & Memenuhi \\
\hline $\begin{array}{l}\text { Uji Heterokesdasitas (VIF } \\
\text { dan Tolarance) }\end{array}$ & Memenuhi \\
\hline $\begin{array}{l}\text { Uji Autokorelasi (Durbin } \\
\text { Watson) }\end{array}$ & $\begin{array}{l}\text { Tidak } \\
\text { Memenuhi }\end{array}$ \\
\hline
\end{tabular}

Menurut Ghozali (2013) uji normalitas dilakukan untuk mengetahui apakah di dalam model regresi, kedua variabel yaitu variabel independen dan dependen mempunyai distribusi data normal atau mendekati normal. Model regresi yang baik adalah model regresi yang memiliki dristribusi normal atau mendekati normal sehingga dapat terhidar dari bias data. Penelitian ini menggunakan analisis statistic Kolmogorov-Smirnov yang mengatakan data berdistribusi normal jika nilai signifikansi atau $\mathrm{p}$ - value $>0.05$. Hasil uji
Kolmogorov-Smirnov pada penelitian ini menunjukan nilai signifikasi 0.373 yang lebih besar daripada 0.05 sehingga dapat disimpulkan data berdistribusi normal.

Pengujian multikulinearitas bertujuan untuk mengatahui apakah di dalam model regresi ditemukan adanya korelasi antar variabel independen. Jika terjadi korelasi maka disebut sebagai masalah multikolinearitas. Nilai Variance Inflation Factors (VIF) $<10$ atau nilai tolerance > 0.10 menunjukan tidak adanya masalah multikolinearitas.

Tabel 2. Hasil Uji Multikolinearitas

\begin{tabular}{|l|c|c|}
\hline \multirow{2}{*}{ Model } & \multicolumn{2}{|c|}{ Collinearity Statistics } \\
\cline { 2 - 3 } & Tolerance & VIF \\
\hline $\begin{array}{l}\text { Kepemilikan } \\
\text { Manajerial }\end{array}$ & 0.909 & 1.100 \\
\hline $\begin{array}{l}\text { Kepemilikan } \\
\text { Institusional }\end{array}$ & 0.959 & 1.043 \\
\hline $\begin{array}{l}\text { Komisaris } \\
\text { Independen }\end{array}$ & 0.973 & 1.028 \\
\hline Komite Audit & 0.895 & 1.118 \\
\hline
\end{tabular}

Dari tabel diatas, terlihat bahwa keseluruhan variabel penelitian telah bebas dari masalah multikolinearitas. Hal ini dapat dilihat pada nilai Tolerance keseluruhan variabel lebih besar dari 0.01 . Selain itu nilai VIF dari keseluruhan variabel memiliki nilai kurang dari 10.

Menurut Ghozali (2013) uji ini bertujuan untuk mengetahui apakah dalam sebuah model regresi terjadi ketidak samaan varian dari residu satu pengamatan ke pengamatan yang lain. Jika variance dari residual satu pengamatan ke pengamatan yan lain tetap, maka disebut homokedastisitas dan jika pengamatan yang satu dan lainnya berbeda disebut dengan heterokedastisitas. Model regresi dikatakan baik jika tidak terjadi gejala heteroskedasitas. Untuk melakukan uji heteroskedasitas penelitian ini menggunakan uji glesjser dengan dasar pengambilan keputusan jika nilai signifikansi diatas 0.05 maka tidak terjadi gejala heteroskedasitas. 
Tabel 3. Tabel Uji Heterokesdasitas

\begin{tabular}{|l|l|}
\hline Model & Sig \\
\hline Kepemilikan Manajerial & 0.970 \\
\hline Kepemilikan Institusional & 0.221 \\
\hline Komisaris Independen & 0.178 \\
\hline Komite Audit & 0.064 \\
\hline
\end{tabular}

Berdasarkan tabel diatas dapat dikatakan bahwa dalam model regresi tidak terjadi gejala heterokesdasitas karena nilai signifikansi dari keempat variabel diatas lebih besar dari 0.05

Dalam penelitian ini uji autokorelasi menunjukan bahwa dalam model regresi terjadi gejala autokorelasi. Namun dalam pengujian goodness of fit, nilai signifikansi pada uji $\mathrm{F}$ menunjukan nilai yang signifikan. Sehingga penelitian ini dapat dilanjutkan.

Tabel 4. Hasil Regresi Linier Berganda

\section{Coefficients $^{\mathrm{a}}$}

\begin{tabular}{|c|c|c|c|c|c|}
\hline \multirow[t]{2}{*}{$\overline{\text { Model }}$} & \multicolumn{2}{|c|}{$\begin{array}{c}\text { Unstandardiz } \\
\text { ed } \\
\text { Coefficients }\end{array}$} & \multirow{2}{*}{\begin{tabular}{|c}
$\begin{array}{c}\text { Standardiz } \\
\text { ed } \\
\text { Coefficient } \\
\text { s }\end{array}$ \\
Beta
\end{tabular}} & \multirow[t]{2}{*}{$\mathrm{t}$} & \multirow[t]{2}{*}{ Sig } \\
\hline & $\bar{B}$ & $\begin{array}{l}\text { Std. } \\
\text { Error }\end{array}$ & & & \\
\hline (Constant) & 8.794 & 1.822 & & $\begin{array}{r}4.82 \\
7\end{array}$ & \\
\hline $\begin{array}{l}\text { Kepemilik } \\
\text { an }\end{array}$ & .016 & .089 & .019 & .180 & .85 \\
\hline $\begin{array}{l}\text { Manajerial } \\
\text { Kepemilik }\end{array}$ & & & & & \\
\hline $\begin{array}{l}\text { an } \\
\text { Institusion } \\
\text { al }\end{array}$ & 4.344 & .845 & .518 & $\begin{array}{r}5.14 \\
2\end{array}$ & .00 \\
\hline $\begin{array}{l}\text { Komisaris } \\
\text { Independe } \\
n\end{array}$ & .442 & .484 & .091. & .913 & $\mid \begin{array}{r}.36 \\
4\end{array}$ \\
\hline $\begin{array}{l}\text { Komite } \\
\text { Audit }\end{array}$ & -.424 & .218 & -.203 & $\begin{array}{r}1.94 \\
7\end{array}$ & .05 \\
\hline
\end{tabular}

a. Dependent Variable: Nilai Perusahaan

Berdasarkan hasil regresi linier berganda pada Tabel 4, dapat disimpulkan persamaan regresi sebagai berikut.
Nilai Perusahaan $=-8,794+0,016 \mathrm{KM}+4,344$ $\mathrm{KI}+0,442 \mathrm{KIn}-0,424 \mathrm{KA}$

Tabel 4 menunjukan Nilai signifikansi dari variabel Kepemilikan Manajerial adalah sebesar 0,858 yaitu lebih besar dari tingkat signifikansi 0,05. Dengan demikian dapat dikatakan bahwa kepemilikan manajerial tidak memiliki pengaruh terhadap peningkatan nilai perusahaan (Hipotesis 1 ditolak). Nilai signifikansi dari variabel kepemilkan institusional menunjukan angka 0,000 yang dimana lebih kecil dari tingkat signifikansi 0,05 dan berkoefisien beta positif, berdasarkan hasil tersebut Kepemilikan dinyakan memiliki pengaruh positif terhadap nilai perusahaan (Hipotesis 2 diterima). Variabel komisaris independen pada tabel 4 menunjukan nilai signifikansi 0,364 yang lebih besar dari tingkat signifikansi 0,05 , sehingga dapat disimpulkan variabel komisaris independen tidak memiliki pengaruh terhadap nilai perusahaan (Hipotesis 3 ditolak). Varibel terakhir pada penelitian ini adalah Komite audit yan menunjukan nilai signifikansi 0,055 yang lebih besar dari tingkat signifikansi 0,05 dengan koefisien beta negative yang berarti jumlah komite audit memiliki pengaruh negative terhadap nilai perusahaan (Hipotesis 4 diterima).

\section{Pengaruh Kepemilikan Manajerial terhadap Nilai Perusahaan}

Hasil menunujukan kepemilikan manajerial tidak memiliki pengaruh terhadap nilai perusahaan. Hal ini sejalan dengan penelitian yang dilakukan oleh Damayanti dan Suartana (2014). Dengan adanya kepemilikan manajerial diharapkan dapat mensejajarkan kepentingan manajemen dan pemegang saham, sehingga dapat mencapai nilai perusahaan yang tinggi. Namun pada kenyataannya, para manajer memiliki kepentingan lain yang tidak mencerminkan tujuan perusahaan secara keseluruhan (Damayanti dan Suartana, 2014). Seperti pada praktik earning management yang dapat menurunkan nilai perusahaan, manajer yang ikut serta menanamkan modalnya di suatu perusahaan cenderung memiliki kepentingan pribadi (Management's Interest) 
berupa keinginan untuk mendapatkan return yang tinggi (Dewi, 2017).

\section{Pengaruh Kepemilikan Institusional terhadap Nilai Perusahaan}

Hasil menunjukan kepemilikan institusional memiliki pengaruh positif terhadap nilai perusahaan. Setiap kenaikan kepemilikan institusional akan meningkat nilai perusahaan. Penelitian ini sejalan dengan penelitian Darmayanti \& Suartana (2014) dan Nuraina (2012) yang menyatakan kepemilikan institusional mampu membatasi perilaku oppurtunistik para manajer. Dengan adanya kepemilikan institusional, pihak institusi dapat melakukan pengawasan operasional untuk meningkat kinerja perusahaan (Muliani et al, 2014). Peningkatan kinerja perusahaan mencerminkan operasional yang baik, juga akan meningkatkan nilai perusahaan (Darwis, 2009).

\section{Pengaruh Komisaris Independen terhadap Nilai Perusahaan}

Hasil menunjukan bahwa komisaris independen tidak memiliki pengaruh terhadap nilai perusahaan. Adanya monitoring yang dilakukan oleh komisaris independen tidak menghalangi perilaku manajer untuk memaksimalkan kepentingan pribadinya sehingga target perusahaan untuk memaksimalkan nilai perusahaan sulit tercapai karena adanya perbedaan kepentingan (Wardoyo dan Veronica, 2014). Selain itu dimungkinkan pula keberadaan komisaris independen dalam perusahaan hanyalah bersifat formalitas untuk memenuhi regulasi, sehingga keberadaan komisaris independen ini tidak untuk menjalankan fungsi monitoring yang baik dan tidak menggunakan independensinya untuk mengawasi kebijakan direksi (Gultom dan Ahmar, 2016).

\section{Pengaruh Komite Audit terhadap Nilai Perusahaan}

Hasil menunjukan jumlah komite audit memiliki pengaruh terhadap nilai perushaan denga arah yg negatif. Sehingga dapat disimpulkan setiap adanya kenaikan jumlah komite audit akan menurunkan nilai perusahaan. Hasil ini bertentangan dengan penelitian yang pernah dilakukan sebelumnya oleh Onasis dan Robin (2016) yang menyatakan adanya pengaruh komite audit terhadap nilai perusahaan. Namun dalam penelitian ini komite audit memiliki pengaruh negative terhadap nilai perusahaan. Mengacu pada surat edaran dari Direksi PT. Bursa Efek Jakarta No. SE-008/BEJ/12-2001 dan kebiijakan Good Corporate Governance Indonesia, investor menganggap bahwa keberadaan komite audit dalam sebuah perusahaan sudah merupakan sebuah kewajiban bagi perusahaan untuk memenuhinya dan menganggap bahwa keberadaan komite audit bukan jaminan kinerja perusahaan menjadi lebih baik. Faktor lain yang mungkin dapat menjelaskan tidak adanya pengaruh komite audit terhadap nilai perusahaan adalah kurang optimalnya kinerja kinerja komite audit dalam menjalankan fungsi pengawasan. Sehingga memunculkan pertanggungjawaban manajemen yang kurang transparan dan mengakibatkan menurunnya kepercayaan para pelaku modal yang menyebabkan nilai perusahaan menurun (Perdana dan Raharja, 2014).

\section{KESIMPULAN}

Hasil penelitian ini menunjukan hanya variabel kepemilikan institusional yang memiliki pengaruh positif dan signifikan terhadap nilai perusahaan. Kepemilikan institusional itu sendiri merupakan kepemilikan saham oleh institusi tertentu yang dipercaya mampu membatasi perilaku opurtunistik dari manajemen yang memiliki perbedaan kepentingan yang tidak sesuai dengan tujuan keseluruhan perusahaan. Sedangkan ketiga variabel yang lain yaitu Kepemilikan manajerial, Komisarin Independen, dan komite audit tidak memiliki pengaruh terhadap nilai perusahaan.

Kepemilikan manajerial pada dasarnya berfungsi untuk menyelaraskan kepentingan manajer dengan kepentingan para pemegang saham yang lain. Diharapkan dengan adanya kepemilikan manajerial ini mampu memotivasi 
para manajer untuk meningkatkan kinerja perusahaan untuk mencapai tujuan perusahaan. Namun dalam penelitian ini kepemilikan manajerial masih belum mampu memberi pengaruh terhadap nilai perusahaan. Hal ini disebabkan karena masih adanya perbedaan kepentingan antara para manajer dengan tujuan keseluruhan perusahaan. Hasil yang sama juga terdapat pada Komisaris Independen dan Komite Audit. Pada penelitian ini komisaris independen dan komite audit tidak memiliki pengaruh terhadap nilai perusahaan. Hal ini mungkin disebabkan karena keberadaan komisaris independen dan komite audit hanya sebagai formalitas untuk memenuhi peraturan yang ada. Selain itu dimungkinkan kurangnya koordinasi, komunikasi dan pengambilan keputusan dalam menjalankan fungsi kontrol antara komisaris independen dan komite audit kepada direksi yang menyebabkan fungsi monitoring yang dilakukan tidak berjalan dengan baik.

\section{SARAN}

Bagi perusahaan- perusahaan BUMN diharapkan dapat memperbaiki komponen Good Corporate Governance dalam kegiatan bisnisnya. Disarankan untuk mempertimbangkan besarnya proporsi kepemilikan manajerial dan kepemilikan institusional. Selain itu juga mempertimbangkan kembali kinerja Komisaris Independen dan Komite Audit dalam menjalankan fungsi pengawasan sehingga fungsi pengawasan dapat berjalan dengan baik untuk tercapainya tujuan perusahaan dan kesejahteraan para pemangku kepentingan.

Bagi peneliti yang ingin melakukan penelitian yang serupa disarankan untuk menambahkan jumlah sampel peneltian atau menggunak sektor usaha lain sebagai objek penelitian. Disarankan pula untuk menambahkan variabel lain yang dapat mewakili Good Corporate Governance.

\section{DAFTAR PUSTAKA}

Achmad, A. R., Rovila, E. M. (2014).
Pengaruh Corporate Social Responsibility (CSR), Kepemilikan Manajerial dan Institusional Terhadap Nilai Perusahaan. Jurnal Manajemen Keuangan. 5(8): h: 114-119

Damayanti, N. P. W. P., \& Suartana, I. W. (2014). Pengaruh Kepemilikan Manajerial dan Kepemilikan Institusional pada Nilai Perusahaan. E-Jurnal Akuntansi, 575-590.

Dewi, W. S., \& Mustikawati, R. I. (2018). Pengaruh Earning Management pada Laporan Keuangan Terhadap Nilai Perusahaan Dengan Dewan Komisaris Independen, Kepemilikan Manajerial, dan Kualitas Audit Sebagai Variabel Moderating (Studi Empiris pada Perusahaan Manufaktur yang Terdaftar di Bursa Efek Indonesia Tahun 2014 dan 2015). Jurnal Profita: Kajian Ilmu Akuntansi, 6(2).

Darwis, H. (2009). Corporate Governance Terhadap Nilai Perusahaan. Jurnal Keuangan Perbankan. Vol. 13, No. 3, 2009. Universitas Khairun Ternate

Embang, E. L. 2016. Pengaruh Corporate Social Responsibility dan Good Corporate Governance Terhadap Nilai Perusahaan Yang Terdaftar di BEI Tahun 2010-1014. Skripsi. Fakultas Ekonomi Universitas Ma Chung.

Felmania, M. (2014). Good Corporate Governance Mechanism, Corporate Social Responsibility Disclosure on Firm Value: Empirical Study on Listed Company in Indonesia Stock Exchange. International Journal of Finance and Accounting Studies, 2(1), 1-10.

Gultom, R.R. \& Ahmar, N. (2016). Model Manajemen Stubben, Tata Kelola dan Nilai Perusahaan Industri Dasar dan Kimia di Indonesia. Jurnal. Universitas Bakrie

Ghozali, I. (2013). Aplikasi Analisis Multivariate Dengan Program SPSS. Semarang: Badan Penerbit Universitas Diponegoro.

Hadiwidjaja, R.A. (2018). Pengaruh Pengungkapan Sustainable Reporting dan 
Good Corporate Governance Terhadap Nilai Perusahaan Dengan Profitablitas Sebagai Variabel Pemoderasi. Skripsi. Fakultas Ekonomi dan Bisnis Universitas Ma Chung

Haruman, T. (2008). Pengaruh Struktur Kepemilikan Terhadap Keputusan Keuangan dan Nilai Perusahaan Survey pada Perusahaan Manufaktur di PT. Bursa Efek Indonesia.

Harjoto, M. A., \& Jo, H. (2007). Why do firms engage in corporate social responsibility. Working Paper). Santa Clara, CA: Santa Clara University.

Jensen, M. C \& Meckling, W.H. (1976). Theory of the Firm : Managerial Behavior, Agency Costs and Ownership Structure . Journal of Financial Economics. Vol. 3, Iss: 4, pp. 305-360.

Marceline, L., \& Harsono, A. (2017). Pengaruh Good Corporate Governance, Karakter Perusahaan, Likuiditas, Leverage, Kebijakan Deviden, dengan Nilai Perusahaan. Jurnal Bisnis dan Akuntansi, 19(1a-3), 226-236.

Muliani, L. E., Yuniarta, G. A., AK, S., \& Sinarwati, N. K. (2014). Pengaruh kinerja keuangan terhadap nilai perusahaan dengan pengungkapan corporate social responcibility dan good corporate governance sebagai variabel pemoderasi. JIMAT (Jurnal Ilmiah Mahasiswa Akuntansi) Undiksha, 2(1).

Ningsih, Hana Ratna. 2013. Pengaruh Kepemilikan Manajerial dan Rasio Pengembalian Aktiva Terhadap Nilai Perusahaan (Studi Kasus pada Industri Perbankan yang Terdaftar di Bursa Efek Indonesia). Jurnal Universitas Komputer Indonesia.

Nugroho, O. C. 2015. Studi Empiris Good Coporate Governance dan Pengungkapan Corporate Social Responsibility Terhadap Nilai Perusahaan. Skripsi. Fakultas Ekonomi Universitas Ma Chung.

Nugroho, D. R., dan Siahaan, R. (2005). BUMN Indonesia Isu, Kebijakan, dan
Strategi. PT. Elex Media Koputindo.

Nuraina, E. (2012). Pengaruh kepemilikan institusional dan ukuran perusahaan terhadap kebijakan hutang dan nilai perusahaan (studi pada perusahaan manufaktur yang terdaftar di BEI). AKRUAL: Jurnal Akuntansi,4(1), 51-70Nurlela, I. (2008). Pengaruh Corporate Social Responsibility Terhadap Nilai Perusahaan Dengan Prosentase Kepemilikan Manajemen Sebagai Variabel Moderating. Simposium Nasional Akuntansi XI.

Nurlela, I. (2008). Pengaruh Corporate Social Responsibility Terhadap Nilai Perusahaan Dengan Prosentase Kepemilikan Manajemen Sebagai Variabel Moderating. Simposium Nasional Akuntansi XI.

Onasis, K., \& Robin, R. (2016). Pengaruh Tata Kelola Perusahaan terhadap Nilai Perusahaan pada Perusahaan Sektor Keuangan yang Terdaftar di BEI. Bina Ekonomi, 20(1), 1-22.

Orchad, C. (2016). Penerapan Good Corporate Governance dalam Upaya Mewujudkan BUMN yang Berbudaya. Jurnal Hukum. 2(2)

Primadhyta, S. (2017). OJK: Praktik GCG Perusahaan Indonesia Masih Tertinggal. diakses dari (https://www.cnnindonesia.com/ekonomi/ 20170920070153-78-242846/ojk-praktikgcg-perusahaan-indonesia-masihtertinggal pada 23 januari 2019

Jimry Poluan, S. (2013). Pengaruh Corporate Governance Terhadap Cash Holdings Perusahaan Di Indonesia Selama Tahun 1993-2007 (Doctoral dissertation, Magister Manajemen Program Pascasarjana UKSW).

Purwaningtyas, F. P., \& PANGESTUTI, I. R. D. (2011). Analisis Pengaruh Mekanisme Good Corporate Governance Terhadap Nilai Perusahaan (Studi Empiris Pada Perusahaan Manufaktur yang Terdaftar di BEI Tahun 2007-2009) (Doctoral dissertation, Universitas Diponegoro). 
Raharja, \& Perdana, R. S. (2014). Analisis Pengaruh Corporate Governance Terhadap Nilai Perusahaan. Jurnal Akuntansi. Vol. 3, No. 3, 2014. Universitas Diponegoro.

Saputra, W. S. (2018, September). -Pengaruh Corporate Governance, Corporate Social Responsibility, dan Intelectual Capital Tehadap Nilai Perusahaan. In National Conference of Creative Industry.

Suharli, M. (2006). Studi Empiris Terhdap Faktor yang Mmempengaruhi Nilai Perusahaan pada Perusahaan Go Public di Indonesia. Maksi, 6.

Syafitri, T., Nuzula, N. F., \& Nurlaily, F. (2018). PENGARUH GOOD CORPORATE GOVERNANCE TERHADAP NILAI PERUSAHAAN (Studi pada perusahaan industri sub sektor logam dan Sejenisnya yang terdaftar di bei periode 2012-2016). Jurnal Administrasi Bisnis, 56(1).

Wardoyo, \& Veronica, T. M. (2013). Pengaruh Good Corporate Governance, Corporatte Social Responsibility, \& Kinerja Keuangan Terhadap Nilai Perusahaan. Jurnal Dinamika Manajemen. Vo. 4, No. 2, 2013. Universitas Gunadarma

Wedayanthi, K. K., \& Darmayanti, N. P. A. (2016). Pengaruh Economic Value Added, Komposisi Dewan Komisaris, Komisaris Independen, dan Return on Asset Terhadap Nilai Perusahaan. E-Jurnal. Vol. 5, No. 6, 2016. Universitas Udayana. 